\title{
Sosialisasi Dan Edukasi Tentang Gerakan 3M Dalam Memutuskan Mata Rantai Penyebaran Covid 19 Di Desa Mentengah Kecamatan Lingga Kabupaten Lingga
}

\author{
Fransiskus Irwan Widjaja ${ }^{1}$ Talizaro Tafonao², Sabar Manahan Hutagalung ${ }^{3}$, Selvyen \\ Sophia $^{4}$, Mangiring Tua Togatorop ${ }^{5}$, Roi Ganda Panggabean ${ }^{6}$, Alfian Paskah Wayoi ${ }^{7}$ \\ 1,3, 4, 5, 6 Prodi Teologi, STT Real Batam \\ 2 Prodi PAK, STT Real Batam \\ *irwanwidjaja.fiw@gmail.com
}

\begin{abstract}
The purpose of this service activity is to increase public understanding in Mentengah Lingga Village, Lingga District, Lingga Regency about preventing the spread of Covid-19. Covid-19 is a virus that damages the human health system and not only affects health, but also affects the economy, politics and social order in society. This activity was carried out by the team/lecturer based on the problems experienced by the community/partners during observations where the community in the village did not follow the health protocols as stipulated by the government. The method of implementing this community service is socialization and education and counseling to partners as well as simulations in carrying out every activity about the $3 M$ movement (wearing masks, keeping distance and washing hands). After this activity is carried out, the results obtained are that the community can carry out and apply it $95 \%$ as explained in this article. This can be seen in the appreciation from the entire community and government when the team/lecturer carries out this activity. Keywords: Socialization, Education, 3M Movement, Simulation, Covid-19
\end{abstract}

\begin{abstract}
Abstrak
Tujuan kegiatan pengabdian ini adalah untuk meningkatkan pemahaman masyarakat di Desa Mentengah Lingga Kecamatan Lingga Kabupaten Lingga tentang pencegah penyebaran Covid-19. Covid-19 ini merupakan virus yang merusak sistem kesehatan manusia dan tidak hanya mempengaruhi dari segi kesehatan saja namun juga mempengaruhi ekonomi, politik dan tatanan sosial di dalam masyarakat. Kegiatan ini lakukan oleh tim/dosen didasarkan pada masalah yang dialami oleh masyarakat/mitra pada saat melakukan observasi dimana masyarakat di Desa tersebut tidak mengikuti protokol kesehatan sebagaimana aturan yang ditetapkan oleh pemerintah. Metode pelaksanaan pengabdian masyarakat ini yakni sosialisasi dan edukasi dan penyeluhan kepada mitra serta simulasi dalam melaksanakan setiap kegiatan tentang gerekan 3M (memakai masker, menjaga jarak dan mencuci tangan). Setelah kegiatan ini dilakukan, hasil yang dapatkan adalah masyarakat dapat melakukan dan menerapkannya 95\% sebagaimana penjelasan dalam artikel ini. Hal ini nampak pada apresiasi dari seluruh masyarakat dan pemerintah pada saat tim/dosen melaksanakan kegiatan ini.

Kata kunci: Sosialisasi, Edukasi, Gerakan 3M, Simulasi, Covid-19
\end{abstract}

\section{PENDAHULUAN}

Sejak Covid-19 ada semua masyarakat mengalami berbagai dampak mulai dari kehidupan sosial, pekerjaan dan kesehatan. Dengan kata lain bahwa Covid-19 ini telah mengacaukan sistem kehidupan didalam masyarakat, sehingga sampai saat ini pemerintah terus mengajak masyarakat untuk menekan terjadinya penyebaran Covid-19 dengan mematuhi protokol kesehatan. Dalam kajian yang dilakukan oleh Mulyadi mengatakan bahwa salah satu kunci dalam menekan terjadinya penyebaran Covid-19 adalah harus ada kesadaran dan partisipasi dari masyarakat seperti melakukan pembatasan sosial (social distancing) dan pembatasan fisik (physical distancing) demi memutuskan mata rantai penyebaran Covid-19. ${ }^{1}$ Selain mematahui hal-hal tersebut di atas, masyarakat juga dihimbau dan diwajibkan untuk memakai masker, mencuci tangan, dan menjaga jarak. Tetapi menurut Pakaya, dkk,

\footnotetext{
${ }^{1}$ Mohammad Mulyadi, "Partisipasi Masyarakat Dalam Penanganan Penyebaran Covid-19," Pusat
} Penelitian Badan Keahlian DPR RI XII, no. 8 (2020): 13-18. 
masih banyak masyarakat yang belum menerapkan 3M (Memakai Masker, Mencuci Tangan, dan Menjaga Jarak $)^{2}$, sehingga tidak heran jika sampai saat ini kasus Covid-19 semakin tinggi.

Kasus-kasus seperti ini masih ditemukan diberbagai tempat. Berdasarkan hasil observasi yang dilakukan oleh tim atau dosen dari Sekolah Tinggi Teologi Real Batam pada 31 Januari - 12 Februari 2021 di Desa Mentengah, Kecamatan Lingga, Kabupaten Lingga mendapatkan bahwa masyarakat di sana masih belum sepenuhnya mengikuti protokol kesehatan sesuai dengan himbauan dan aturan pemerintah khususnya dalam memakai masker, mencuci tangan, dan menjaga jarak.

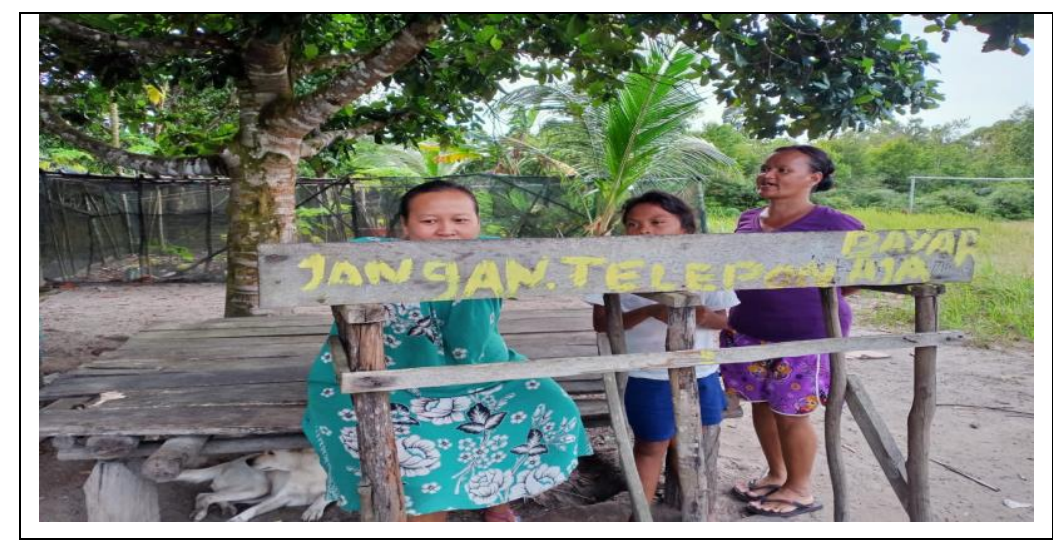

\section{Gambar 1. Warga yang tidak memakai masker pada saat survei awal di Desa Mentengah}

Setelah tim melihat kondisi ini di lapangan maka tim dan dosen bergerak membuat tim pelaksana dalam mengadakan sosialisasi dan edukasi kepada masyarakat tentang pentingnya menjaga kesehatan selama masa pandemi. Dengan melaksanakan sosialisasi dan edukasi seperti ini maka masyarkat memiliki pemahaman dan pengetahuan dalam memutuskan penyebaran Covid-19 di masyarakat serta ikut membantu pemerintah.

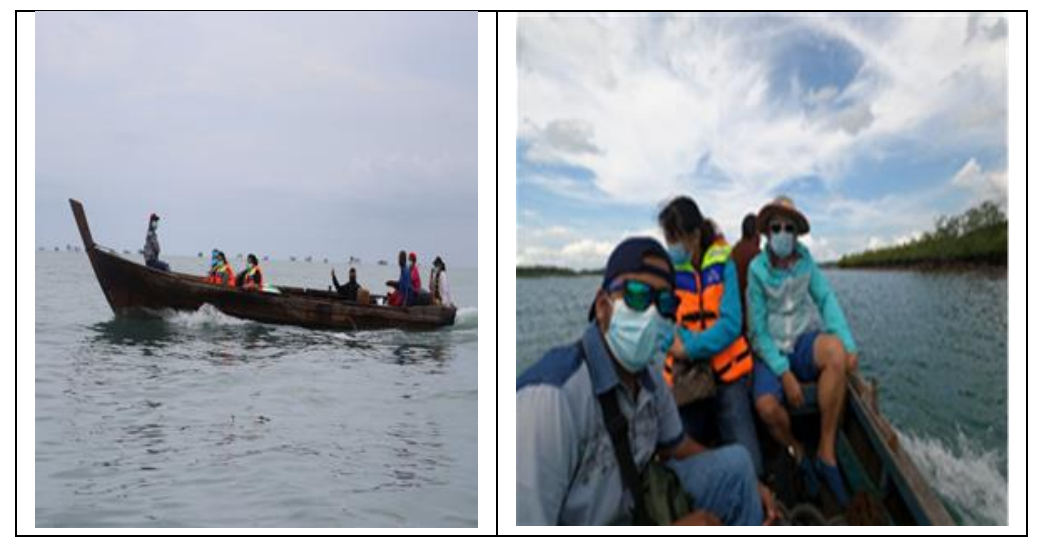

\section{Gambar 1. Tim atau Dosen sedang menuju lokasi di Desa Mentengah Lingga}

Perjalanan menuju Desa Mentengah ini dapat di tempuh selama 1,5 jam dengan menggunakan Transportasi Pompong dan dapat juga di lalui melalui Hulu Sungai selama 45 menit dari Pulau Daratan Daik Lingga. Secara geografis Kabupaten Lingga merupakan salah satu Kabupaten yang ada di Provinsi Kepulauan Riau. Kabupaten ini terbentuk pada tahun 2003, hasil pemekaran dari Kabupaten Kepulauan Riau. Rata-rata masyarakat yang ada di Kabupaten ini mulai dari umur 15 ke

${ }^{2}$ Ririn Pakaya et al., "Penerapan 3 M (Memakai Masker, Mencuci Tangan Dan Menjaga Jarak) Dalam Upaya Pencegahan Penularan Corona Virus Disease (Covid-19) Di Desa Mohiyolo Kec. Asparaga Kabupaten Gorontalo," Jurnal Pengabdian Kepada Masyarakat Universitas Gorontalo 3, no. 1 (2021): 1-9, https://jurnal.unigo.ac.id/index.php/insancita/article/view/1415/644. 
atas lebih banyak memilih bekerja daripada memilih untuk melanjutkan sekolah. ${ }^{3}$ Selain itu, dari segi kesehatan masyarakat ini sangat membutuhkan ketersediaan sarana dan prasarana khususnya dalam kesehatan serta tenaga medis yang selalu memberi edukasi berkaitan dengan kesehatan. ${ }^{4}$ Dua hal ini yang menjadi perhatian penting dari tim atau dosen dari Sekolah Tinggi Teologi Real Batam, yaitu kesehatan dan pendidikan karena mengingat penyebaran Covid-19 saat ini belum selesai. Aktifitas seperti ini menurut Sulaeman dan Supriadi sangat penting dilakukan didalam masyarakat karena kondisi saat ini sangat membutuhkan perhatian dari semua kalangan demi menekan terjadinya penyebaran wabah Covid-19 serta keresahan diantara masyarakat, oleh karena itu perlu diberi pengetahuan dan pemahaman mengenai informasi tentang Corona Virus sekaligus cara mencegahnya. ${ }^{5}$

Kegiatan pengabdian yang dilakukan ini merupakan kewajiaban dari para dosen dalam berkontribusi di masyarakat. Selain itu, pengabdian ini salah satu indikator penting dari Tri Dharma Perguruan Tinggi. Dalam melaksanakan kegiatan ini kepada masyarakat/mitra tidak mudah karena masih dalam situasi pandemi dan juga medan yang ditempuh cukup menantang seperti gambar di atas. Tetapi demi tercapaian suatu kegiatan di masyarakat maka para tim berupaya untuk sampai di lokasi. Tujuan dari kegiatan pengabdian ini adalah untuk meningkatkan pemahaman masyarakat tentang pencegah penyebaran Covid-19.

\section{METODE}

Kegiatan pengabdian kepada masyarakat ini dilaksanakan selama 4 hari mulai 6 sampai 9 April 2021 di Desa Mentengah Kecamatan Lingga Kabupaten Lingga. Metode yang dilakukan dalam membantu mitra dalam memahami dan menyelesaikan permasalahan adalah penyuluhan dengan tema Sosialisasi Dan Edukasi Tentang Gerakan 3M dalam Memutuskan Mata Rantai Penyebaran Covid 19 Di Desa Mentengah Kecamatan Lingga Kabupaten Lingga menggunakan metode pendekatan adalah ceramah, pendampingan dan simulasi dalam melakukan gerekan 3M (memakai masker, menjaga jarak dan mencuci tangan) dengan menyediakan wadah cuci tangan, sabun, air bersih yang digunakan untuk mencuci tangan, masker yang dibagikan kepada masyarakat, serta mengatur tempat duduk dengan jarak 1 meter setiap peserta. Sosialisasi dan edukasi gerakan 3M ini dimulai dengan memberikan pengetahuan tentang penggunaan masker, Simulasi cara menggunakan masker, Simulasi mencuci tangan dan Simulasi dalam menjaga jarak. Setelah kegiatan ini dilakukan maka tim melakukan evaluasi. Evaluasi ini bertujuan untuk mengukur keberhasilan dalam melaksanakan seluruh kegiatan. Salah satu cara mengukurnya adalah setiap anggota tim/penanggung jawab kegiatan melaporkan kepada ketua tim pengabdian bahwa kegiatan telah dilaksanakan dengan baik sesuai dengan target yang sudah tetapkan. Dan hasilnya terbukti pada setiap kinerja yang sudah tercapai serta berjalan dengan baik dan lancar.

\section{HASIL DAN PEMBAHASAN \\ Edukasi Pengenalan tentang penggunaan masker}

Berbagai upaya yang dilakukan oleh pemerintah dalam menyadarkan setiap masyarakat dalam mengikuti protokol kesehatan selama pandemi ini. Tetapi ternyata masih ada beberapa masyarakat yang belum mematuhi aturan-atauran tersebut dengan berbagai alasan, seperti tidak ada masker, penggunaan masker tidak konsisten, belum ada orang di sekitarnya yang terinfeksi Covid-19, menggunakan masker mengganggu pernafasan dan aktifitas sehari-hari sehingga masyarakat malas menggunakan masker. Selain itu masyarkat juga sering menjadi korban berita hoax yang disebarkan

${ }^{3}$ H. Daria, Buku Putih Sanitasi Kabupaten Lingga Percepatan Pembangunan Sanitasi Permukiman ( PPSP ), 2014.

${ }^{4}$ H. Alias Wello, Laporan Kinerja Insransi Pemerintah (LKjIP), 2019.

${ }^{5}$ Sulaeman and Supriadi, "Peningkatan Pengetahuan Masyarakat Desa Jelantik Dalam Menghadapi Pandemi Corona Virus Diseases-19 (Covid-19)," Jurnal Pengabdian UNDIKMA 1, no. 1 (2020): 12-17. 
melalui media sosial berkaitan dengan isu-isu bahwa Covid-19 tidak ada. Akibatnya banyak masyarakat tidak lagi percaya dengan anjuran-anjuran dari pemerintah. Salah satu sebabnya menurut Atmojo, dkk, bahwa kebijakan dalam menggunakan masker selam ini masih terus terjadi perdebatan sejak adanya Covid-19. ${ }^{6}$

Persoalan-persoalan di atas masih didapatkan diberbagai tempat misalnya di Desa Mentengah Kecamatan Lingga Kabupaten Lingga. Masyarakat di sana tidak menggunakan masker selama beraktifitas di luar rumah sampai dalam kehidupan sosial dalam masyarakat sebagaimana penjelasan dan gambar yang ada di latar belakang di atas. Sebagian besar aktifitas masyarakat ini adalah nelayan. Dalam menjalankan aktifitas sehari-hari para mitra ini merasa bahwa tidak ada Covid-19.

Selain mereka tidak memahami adanya Covid-19 ini, mereka juga menyadari bahwa belum memiliki pengetahuan tentang manfaat penggunaan masker sebagai pencegah penularan penyakit Corona Virus. Berdasarkan persoalan dan alasan-alasan tersebut di atas maka tim pengabdian masyarakat hadir untuk memberi pemahaman dan pengetahuan kepada mitra (masyarakat), agar masyarakat tidak mengabaikan setiap anjuran dari pemerintah khususnya dalam menggunakan masker.

Ada beberapa materi penting yang disampaikan kepada mitra saat itu, yakni manfaat penggunaan masker. Kedisiplinan dalam memakai masker telah menolong diri sendiri dan orang lain khususnya pencegah penularan Covid-19. Melalui alat peraga yang disampaikan oleh dokter kepada mitra saat itu menegaskan bahwa seseorang yang tidak memakai masker dan tidak menjaga jarak maka akan sangat rentan tertular dengan Virus Corona. Berikut ini poin-poin penting yang menjadi perhatian dan pengetahuan kepada mitra saat itu, yaitu: (1) Pada saat seseorang tidak menggunakan masker secara tidak langsung dirinya telah membawa virus corona. Dan Virus corona ini akan tertular ketika berbicara kepada orang lain $100 \%$. (2) Ketika seseorang pembawa virus corona namun memakai masker, lalu bicara dengan orang lain yang tidak memakai masker maka penularan akan turun ke angka $70 \%$. (3) Ketika seseorang yang belum tertular virus corona memakai masker lalu berbicara dengan orang lain yang mungkin OTG tapi tidak pakai masker maka risiko penularan hanya 5\%. (4) Jika semua orang sama-sama pakai masker saat bicara maka risiko penularan hanya $1,5 \%$.

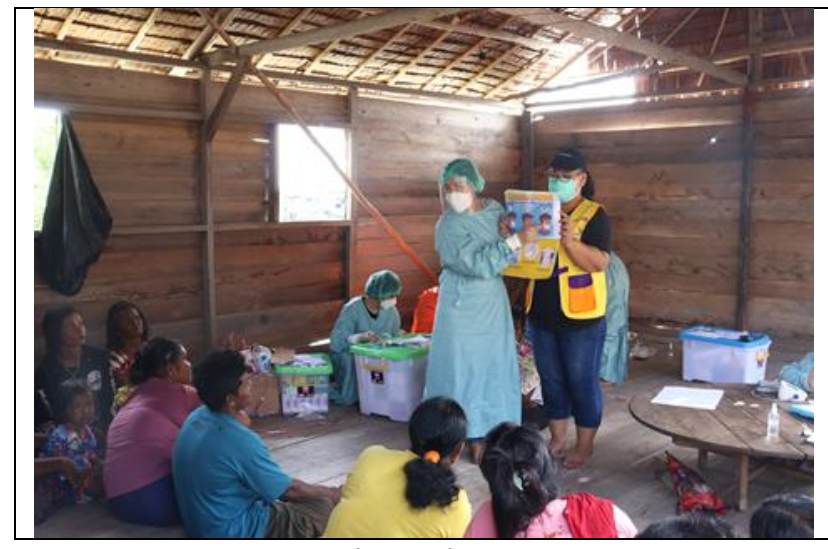

Gambar 3. Foto pada saat pemateri menjelaskan tentang penggunaan masker dalam mencegah Covid-19

\section{Simulasi cara menggunakan masker}

Setelah diberi pengetahuan tentang penggunaan masker serta manfaatnya kepada mitra, maka materi selanjutnya adalah cara menggunakan masker yang baik. Pada umumnya orang menggunakan masker tetapi tidak mengikuti aturan-aturan yang ada. Membawa masker namun tidak memakai dengan baik. Hal-hal seperti ini banyak masyarakat mengabaikannya karena merasa sehat sehingga tidak dilaksanakan. Menurut hemat Nopita menggunakan Alat Pelindung Diri (APD), yakni masker

\footnotetext{
${ }^{6}$ Joko Tri Atmojo et al., "Penggunaan Masker Dalam Pencegahan Dan Penanganan Covid-19: Rasionalitas, Efektivitas, Dan Isu Terkini," Avicenna : Journal of Health Research 3, no. 2 (2020): 84-95.
} 
salah satu cara memutuskan penularan Covid-19.7 Artinya bahwa dengan menggunakan alat tersebut telah mencegah transmisi dari Covid-19. ${ }^{8}$

Dengan melihat berbagai kasus selama pandemi ini maka dalam kegiatan ini para pemateri memberi pemahaman dan pengetahuan kepada mitra tentang cara menggunakan masker yang benar dan tepat berdasarkan aturan medis. Salah satu hal yang perlu diketahui oleh mitra/masyarakat sebelum menggunakan masker adalah antara lain: (1) mencuci tangan dengan sabun terlebih dahulu baru memakai masker. (2) pegang tali masker dengan menggunakan ujung jari sehingga masker tersebut menutup hidung, mulut, dan dagu dengan sempurna. (3) tekan tepi masker yang kaku sesuai dengan lekuan hidung. (4) Lepaskan maskernya dengan memegang tali dan jangan menyentuh bagian depan masker. (5) Setelah melepaskan masker maka kembali mencuci tangan dengan sabun atau menggunakan hand sanitezer.

Dengan simulasi seperti ini para mitra sangat tertolong dalam mehami keberadaan Covid-19 yang semakin mewabah, karena selama ini belum memiliki pengetahuan dan pengalaman dalam mencegah penularan Covi-19. Selain memahami simulasi seperti ini para mitra memiliki pengetahuan dalam menolong diri sendiri dan orang lain dengan tetap mengikuti protokol kesehatan sehingga penyebaran Covid-19 dapat teratasi dengan baik. Para tim menghimbau kepada para mitra agar selalu mematuhi segala aturan yang ada pada saat melakukan segala aktifitas di luar rumah, dengan tidak mengabaikan tata cara memakai masker, karena dengan mengabaikan hal tersebut berarti mitra/masyarakat tidak mendukung pemerintah yang sedang beruapaya menangani Covid-19.

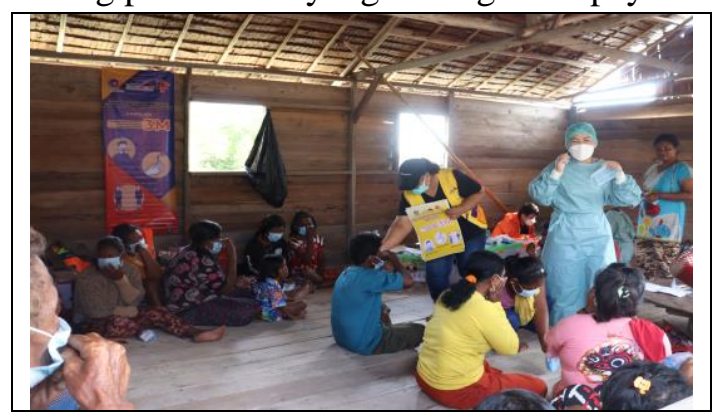

Gambar 4. Simulasi cara menggunakan masker yang benar

\section{Simulasi mencuci tangan}

Sejak adanya Covid-19 di Indonesia gerakan mencuci tangan telah menjadi kegitan rutin yang di lakukan oleh masyarakat selama pandemi. Menurut hemat Salsabila, dkk bahwa mencuci tangan dengan sabun dan air yang mengalir salah satu tindakan yang paling efektif yang dapat mengurangi penyebaran Covid- 19.9 Pengertian seperti ini tidak semua masyarakat dapat memahaminya dan melakukannya terutama orang-orang yang ada di pedesaan. Masyarakat yang ada di kota mencuci tangan di masa pandemi sudah menjadi aktifitas rutin di lakukan setiap waktu. Karena orang kota berpikir bahwa kesehatan sangat mahal sehingga mau tidak mau mereka lakukannya demi keselamatan bersama. Tetapi sangat bertolak belakang dengan pola pikir orang yang ada di Desa bahwa mencuci tangan hanya pada saat makan saja.

${ }^{7}$ Ni Made Nopita Wati et al., "Optimalisasi Penggunaan Alat Perlindungan Diri (APD) Pada Masyarakat Dalam Rangka Mencegah Penularan Virus COVID-19,” Jurnalempathy.Com 1, no. 1 (2020): 1-8.

${ }^{8}$ Santy Irene Putri, "Studi Literatur: Efektivitas Penggunaan Masker Kain Dalam Pencegahan Transmisi Covid-19,” Jurnal Kesehatan Manarang 6, no. khusus (2020): 10.

${ }^{9}$ Alya Fadhilah Salsabila et al., "Implementasi Program Mencuci Tangan Dalam Memutus Mata Rantai Penyebaran Co Vid-19," Angewandte Chemie International Edition 6, no. 11 (2020): 1-8. 
Kasus seperti ini ditemui di Desa Mentengah Kecamatan Lingga Kabupaten Lingga, para mitra/masyarakat mengatakan bahwa mencuci tangan bukan kegiatan rutin yang dilakukan. Dengan persoalan seperti ini sehinga tim atau dosen dari Sekolah Tinggi Teologi Real Batam mengadakan simulasi cara mencuci tangan yang benar dan bermanfaat bagi kesehatan mitra. Aktifitas seperti ini menurut Fauziah, dkk dapat memberikan pengalaman belajar secara perorangan, keluarga, kelompok dan masyarakat dalam meningkatkan pengetahuan, sikap dan perilaku sehingga membantu mesyarakat agar menerapkan cara-cara hidup yang sehat dalam rangka menjaga, memelihara, dan meningkatkan kesehatan. ${ }^{10}$

Jika para mitra/masyarakat tidak mengerti cara mencuci tangan yang benar maka tangan ini menjadi salah satu tempat berkumpulnya kuman. Dalam ilmu medis menegaskan bahwa tangan akan bersentuhan dengan berbagai kotoran ataupun cairan tubuh lain seperti ingus, dan makanan/minuman yang terkontaminasi saat tidak dicuci dengan sabun dan hal ini dapat memindahkan bakteri, virus, dan parasit pada orang lain yang tidak sadar bahwa dirinya sedang ditularkan oleh virus termasuk Corona Virus. Karena tangan salah satu agen yang sering membawa kuman dan menyebabkan patogen berpindah dari satu orang ke orang lain, baik dengan kontak langsung ataupun kontak tidak langsung. Dengan adanya simulasi gerakan mencuci tangan yang dilakukan di Desa Mentengah Kecamatan Lingga Kabupaten Lingga ini salah satu tindakan sanitasi dengan membersihkan tangan dan jari jemari menggunakan air dan sabun. Dengan kata lain bahwa mencuci tangan dengan sabun salah satu upaya pencegahan penyakit Covid-19. Berikut ini adalah langkah-langkah yang harus dilakukan oleh mitra/masyarakat dalam mencuci tangan, yaitu: (1) Mencuci tangan dengan sabun dan air mengalir. (2) Mencuci tangan minimal 20 detik. (3) Ratakan sabun dengan kedua telapak tangan. (4) Gosok punggung dan sela-sela jari tangan kiri dengan tangan kanan dan sebaliknya. (5) Gosok sela-sela jari. (6) Punggung jari tangan kanan digosokkan pada telapak tangan kiri dengan jari sisi dalam kedua tangan saling mengunci. (7) Ibu Jari tangan kiri digosok berputar dalam genggaman tangan kanan dan sebaliknya. (8) Gosok berputar ujung jari tangan kanan di telapak tangan kiri dan sebaliknya.

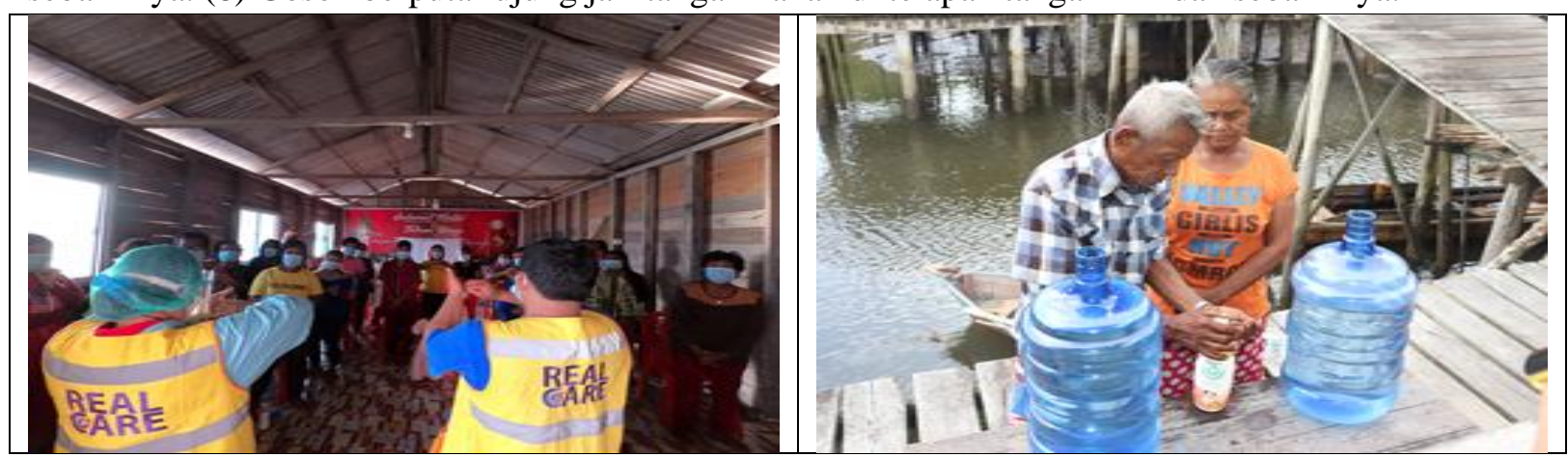

Gambar 5. Foto simulasi gerakan mencuci tangan

\section{Simulasi dalam menjaga jarak}

Salah satu cara dalam memutuskan mata rantai penyebaran virus corona saat ini adalah dengan melakukan physical distancing atau menjaga jarak antar satu dengan yang lain. Organisasi Kesehatan Dunia (WHO) melihat bahwa cara seperti ini paling efektif yang harus di terapkan oleh masyarakat dalam menekan penyebaran Covid-19. Dalam kegiatan yang dilakukan oleh Ertiana, dkk di di Desa Maduretno Kecamatan Papar Kabupaten Kediri menegaskan bahwa semua masyarakat harus tetap menjaga jarak selama pandemi Covid-19 agar mengurangi interaksi antara orang dalam suatu

${ }^{10}$ Munaya Fauziah, Adithya Raidipa Wisesa, and Ade Ratna Nirmala, "Sosialisasi Protokol New Normal," in Seminar Nasional Pengabdian Masyarakat LPPM UMJ, 2020, 1-6. 
komunitas yang lebih luas. Alasannya adalah setiap percikan droplet ketika bersin dan batuk dapat transmisi virus kepada yang lain. ${ }^{11}$

Dengan melihat dampak dari kerumunan tersebut maka tim atau dosen mengedukasi para mitra yang ada di Desa Lingga Kabupaten Lingga untuk memahami betapa pentingnya menjaga jarak dalam melakukan segala kegiatan di masyarakat sehingga penyebaran Covid-19 saat ini dapat teratasi dengan baik. Dalam simulasi ini ada beberapa hal yang diperhatikan dan dilakukan oleh para mitra yakni: (1) menentukan batasan jarak sosial saat berketemu dengan orang lain. (2) menghindari kerumunan dan keramaian. (3) menjaga jarak saat beraktivitas di luar rumah. (4) mengurangi mobilitas. (5) tinggal dirumah untuk tidak melakukan kontak langsung dengan orang lain. Dalam penyuluhan yang dilakaukan oleh Kandari dan Ohorella menuturkan bahwa pembatasan sosial yang diterapkan oleh pemerintah kepada masyarakat merupakan suatu cara untuk menghindari terjadinya kontak fisk selama Covid-19. ${ }^{12}$ Dengan kata lain bahwa instruksik menerapkan physical distancing atau menjaga jarak adalah agar masyarakat menahan diri dan tetap bekerja dari rumah, sekalipun hal ini menjadi polemik dalam menerapkannya sampai saat ini.

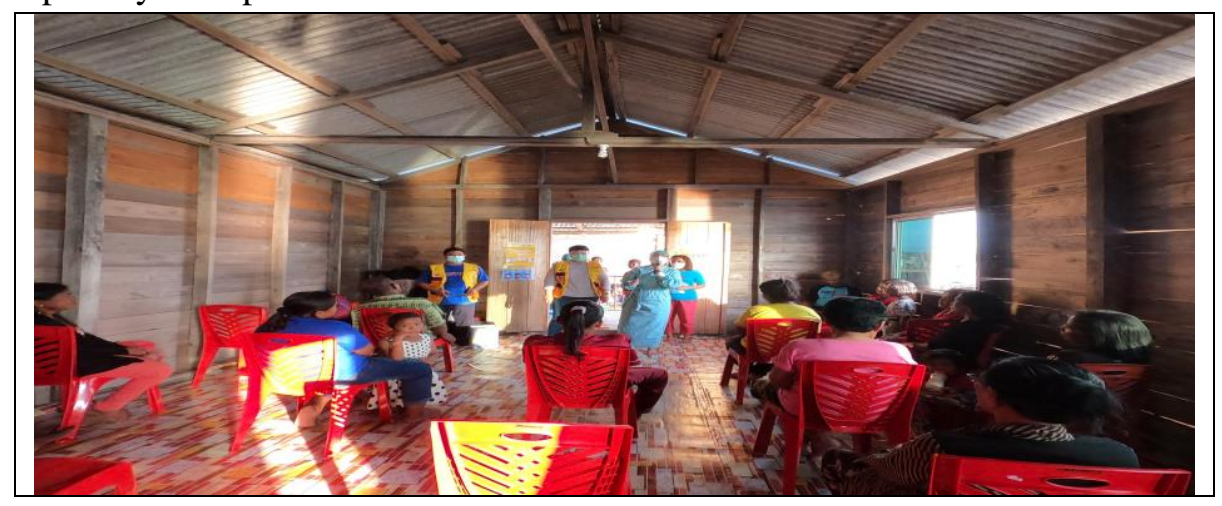

Gambar 6. Foto pada saat menjelaskan simulasi dalam menjaga jarak

Kegiatan pengabdian ini sangat diapresiasikan oleh masyarakat Desa Mentengah Lingga, karena sebelumnya belum pernah mendapatkan penjelasan secara detail tentang Covid-19 dan kegiatan yang dilakukan oleh tim ini dapat memberi pemhaman, pengertian dan pengetahuan serta informasi baru berkaitan munculnya Covid-19. Apresiasi lain yang ditunjukkan oleh masyarakat dapat dilihat dari antusiasme mereka dalam mengikuti setiap sesi demi sesi selam 4 hari. Selain itu masyarakat ini sangat aktif dalam bertanya disetiap diskusi yang dipandu oleh tim khusunya dengan topik kesehatan dalam menghadapi penyebaran Covid-19.

Hasil yang didapat dalam kegiatan pengabdian ini adalah masyarakat mengalami perubahan dalam berpikir (mindset) secara signifikan dari sebelumnya. Setelah menerima dan diedukasi dengan benar tentang gerakan 3M (memakai masker, menjaga jarak dan mencuci tangan) masyarakat diharapkan terus berupaya menerapkannya dalam kehidupan sehari-hari demi memutuskan mata rantai Covid-19 serta turut mengambil bagian menjadi pelopor kesehatan kepada masyarakat yang lain. Hal ini juga yang dipesankan oleh pemerintah kepada seluruh masyarakat Indonesia bahwa partisipasi masyarakat menjadi kunci utama dalam menghentikan penyebaran Covid-19 ini. Dengan demikian

${ }^{11}$ Dwi Ertiana et al., "Peningkatan Peran Serta Masyarakat Dalam Pencegahan Covid-19 Di Desa Maduretno Kecamatan Papar Kabupaten Kediri," Darmabakti : Jurnal Pengabdian dan Pemberdayaan Masyarakat 1, no. 2 (2020): 23-33.

${ }^{12}$ Nahira Kandari and Fadjriah Ohorella, "Penyuluhan Physical DistancingPada Anak Di Panti Asuhan Al Fikri," Jurnal Abdimas Kesehatan Perintis 2, no. 1 (2020): 37-41, https://jurnal.stikesperintis.ac.id/index.php/JAKP/article/view/441/254. 
bahwa kegiatan pengabdian yang dilakukan oleh tim/dosen kepada mitra/masyarakat sangat bermanfaat untuk mendukung program pemerintah saat ini.

\section{SIMPULAN}

Kegiatan pengabdian yang dilakukan di Desa Mentengah Lingga Kecamatan Lingga Kabupaten Lingga telah berjalan dengan baik sesuai dengan tujuan dari pengabdian masyarakat. Hasil kegiatan dari pengabdian masyarakat ini telah memberikan dampak positif kepada mitra, yakni (1) mitra/masyarakat telah mendapat pemahaman dan penjelasan tentang manfaat gerekan $3 \mathrm{M}$ dalam memutuskan mata rantai penyebaran Covid-19. (2) mitra/warga Desa Mentengah telah mendapatkan pengetahuan mengenai pola hidup bersih dan sehat selama pandemi. (3) para mitra dapat menerapkannya lewat kehidupan sehari-hari dengan tetap mengikuti protokol kesehatan sebagaimana penjelasan dalam artikel ini. Inisiatif dari tim pengabdian masyarakat sangat patut diapresiasi dan didukung penuh oleh para pimpinan dan dosen yang telah tergabung dalam tim pengabdian masyarakat dengan melakukan sosialisasi dan edukasi tentang gerakan 3M sehingga kegiatan ini dapat terlaksana dengan baik.

Oleh karena itu sebelum memasuki pernikahan maka sangat dianjurkan calon pasangan untuk melakukan konseling Pra nikah sehingga dapat mengenal pasangan masing-masing serta mempersiapkan mental dan spiritual dalam menghadapi segala permasalahan dikemudian hari.

\section{DAFTAR PUSTAKA}

Atmojo, Joko Tri, Sri Iswahyuni, Rejo Rejo, Catur Setyorini, Kiki Puspitasary, Heni Ernawati, Ahmad Rois Syujak, et al. "Penggunaan Masker Dalam Pencegahan Dan Penanganan Covid-19: Rasionalitas, Efektivitas, Dan Isu Terkini." Avicenna : Journal of Health Research 3, no. 2 (2020): 84-95.

Daria, H. Buku Putih Sanitasi Kabupaten Lingga Percepatan Pembangunan Sanitasi Permukiman ( PPSP ), 2014.

Ertiana, Dwi, Maria Ulfa, Aspiyani Aspiyani, Silaturrokhmah Silaturrokhmah, and Nur

Widya Yuda Prastiwi. "Peningkatan Peran Serta Masyarakat Dalam Pencegahan Covid-

19 Di Desa Maduretno Kecamatan Papar Kabupaten Kediri." Darmabakti : Jurnal

Pengabdian dan Pemberdayaan Masyarakat 1, no. 2 (2020): 23-33.

Fauziah, Munaya, Adithya Raidipa Wisesa, and Ade Ratna Nirmala. "Sosialisasi Protokol

New Normal.” In Seminar Nasional Pengabdian Masyarakat LPPM UMJ, 1-6, 2020.

Kandari, Nahira, and Fadjriah Ohorella. "Penyuluhan Physical DistancingPada Anak Di Panti

Asuhan Al Fikri." Jurnal Abdimas Kesehatan Perintis 2, no. 1 (2020): 37-41.

https://jurnal.stikesperintis.ac.id/index.php/JAKP/article/view/441/254.

Mulyadi, Mohammad. "Partisipasi Masyarakat Dalam Penanganan Penyebaran Covid-19."

Pusat Penelitian Badan Keahlian DPR RI XII, no. 8 (2020): 13-18.

Pakaya, Ririn, Firdaus Ramadhani, Sunarti Hanapi, Franning Deisi Badu, and Ismelda Iyou.

"Penerapan 3 M (Memakai Masker, Mencuci Tangan Dan Menjaga Jarak) Dalam Upaya

Pencegahan Penularan Corona Virus Disease (Covid-19) Di Desa Mohiyolo Kec.

Asparaga Kabupaten Gorontalo.” Jurnal Pengabdian Kepada Masyarakat Universitas

Gorontalo 3, no. 1 (2021): 1-9.

https://jurnal.unigo.ac.id/index.php/insancita/article/view/1415/644.

Putri, Santy Irene. "Studi Literatur: Efektivitas Penggunaan Masker Kain Dalam Pencegahan

Transmisi Covid-19.” Jurnal Kesehatan Manarang 6, no. khusus (2020): 10.

Salsabila, Alya Fadhilah, Audhea Kartini P, Dhea Figi Anyelir, Mishbah Arif S, and Moh.

Firdaus. "Implementasi Program Mencuci Tangan Dalam Memutus Mata Rantai 
Penyebaran Co Vid-19.” Angewandte Chemie International Edition 6, no. 11 (2020): 18.

Sulaeman, and Supriadi. "Peningkatan Pengetahuan Masyarakat Desa Jelantik Dalam

Menghadapi Pandemi Corona Virus Diseases-19 (Covid-19)." Jurnal Pengabdian

UNDIKMA 1, no. 1 (2020): 12-17.

Wati, Ni Made Nopita, Ni Kadek Yuni Lestari, Desak Made Ari Dwi Jayanti, and Nyoman Sudarma. "Optimalisasi Penggunaan Alat Perlindungan Diri (APD) Pada Masyarakat Dalam Rangka Mencegah Penularan Virus COVID-19.” Jurnalempathy.Com 1, no. 1 (2020): 1-8.

Wello, H. Alias. Laporan Kinerja Insransi Pemerintah (LKjIP), 2019. 